\title{
Annual Report of the Chairman of the Anglo-Belarusian Society for 2013-2014
}

\author{
BY \\ JIM DINGLEY
}

The past year was marked by several occasions at which members and friends came together for meetings that were both convivial and instructive:

Annual General Meeting for 2012 - 9 February;

Mother Language Day - 9 March; a unique opportunity to involve both 'Anglos' and Belarusians in poetry reading. The importance of this now traditional annual event is that children play an active part;

Relaunch of the Journal of Belarusian Studies - 21 May. A reception to mark this very special occasion was held in the School of Slavonic and East European Studies, University College London;

Talk by Simon Lewis 'Memory at War in Belarus: Official Myths and Cultural Resistance' - 1 June. Unfortunately the planned meeting with the bard singer Źmicier Vajciuškievič had to be cancelled; we hope to be able to invite him to this country at a later date;

Kupalle - 22 June. Always a lively occasion; special thanks are due to all who helped with the flower garlands, games, building the bonfire, jumping over it, and then launching the garlands on to Dollis Brook;

Reception in honour of Mrs Helen Michaluk, to celebrate her long-standing chairmanship of the Association of Belarusians in Great Britain - 28 September. I was very pleased to be able to present her with a token of the respect and affection in which she is held by the Society. The writer and publisher Ź micier Višnioŭ gave a lively recital of his own poetry on the occasion.

Batlejka - 21 December. A special event for the children and those of us who retain some memory of what it was like to be a child, built around a puppet presentation by Paval Šaǔcoǔ and Saša Bielavokaja. Many thanks to them both.

As always, the Society is very much in the debt of the Association of Belarusians in Great Britain, the Belarusian Catholic Mission and Fr Stasievič in particular, for their unfailing support and permission to use their premises for our meetings. 
This is the last report that I shall write as Chairman of the Society. I have always striven to earn the trust that members and friends of the Society have placed in me, and I earnestly hope that I have to some extent justified that trust. It has been an honour and a real pleasure to have served the Society.

I look forward to many years of regular contact with the Society, now that it is in the hands of Brian Bennett, to whom I am truly grateful for finally yielding and agreeing to take over, in this year that marks the sixtieth anniversary of the Society's existence.

I find it exhilarating to write this report on the very eve of an international conference on Kastuś Kalinoŭski, being held on 27 - 29 March to honour his memory on the $150^{\text {th }}$ anniversary - almost to the day - of his execution in Viĺnia, and also to mark this important landmark in the history of the Society. 